\title{
Concentration of Serum and Urine Creatinine in Children and Adolescents
}

\author{
Se-Young Kwon and Young-Ak Na \\ Department of Biomedical Laboratory Science, Daegu Health College, Daegu 702-722, Korea
}

\begin{abstract}
Creatinine is a general marker as a screening test for renal disease. This study was conducted to provide basic data about pediatric concentration for serum and urine creatinine. The data from the 2011 Korean National Health and Nutrition Examination Survey was used. Analysis was done on 488 Children and Adolescents (boys 278, girls 210) aged 10 to 19, the Jaffe reaction method was used to gather the data. The highest serum creatinine levels were found in boys aged 19 to 20 years, the mean being $0.97 \mathrm{mg} / \mathrm{dL}(\min 0.81 \mathrm{mg} / \mathrm{dL}$, $\max 1.14 \mathrm{mg} / \mathrm{dL}$ ). The levels showed increase over those in the 10 year old group. The highest urine creatinine levels were found aged 19 to 20 years, and the mean was $222.68 \mathrm{mg} / \mathrm{dL}$ ( $\mathrm{min} 133 \mathrm{mg} / \mathrm{dL}$, $\max 324 \mathrm{mg} / \mathrm{dL}$ ). In the case of girls, the highest serum creatinine levels were found with those aged between 18 and 19, the mean being $0.71 \mathrm{mg} / \mathrm{dL}$ ( $\min 0.49 \mathrm{mg} / \mathrm{dL}$, $\max 0.84 \mathrm{mg} / \mathrm{dL}$ ). The levels showed increase over the 11 to 18 year old group. The highest urine creatinine levels were found aged 14 to 15 years, and the mean was $218.44 \mathrm{mg} / \mathrm{dL}$ ( $\min 131 \mathrm{mg} / \mathrm{dL}$, max $321 \mathrm{mg} / \mathrm{dL}$ ). The mean difference in serum creatinine in all age groups was statistically significant except for those aged 10 to 14 , that of urine creatinine in all age groups was not significant statistically except for those aged 12 to 13,17 to 18 . Therefore, it is suggested that reference values for children and adolescents should be divided into different groups according to gender, further studies are needed using complementing data of the pediatrics.
\end{abstract}

Keywords: Serum creatinine, Urine creatinine, Children \& Adolescent

This is an Open Access article distributed under the terms of the Creative Commons Attribution Non-Commercial License (http://creativecommons.org/licenses/by-nc/3.0) which permits unrestricted non-commercial use, distribution, and reproduction in any medium, provided the original work is properly cited.

Copyright (C) 2014 The Korean Society for Clinical Laboratory Science. All rights reserved.
Corresponding author: Se-Young Kwon Department of Biomedical Laboratory Science, Daegu Health College, Daegu 702-722, Korea Tel: 82-53-320-1362

E-mail:sykwon@dhc.ac.kr

Received: November 27, 2014

Revised: December 29, 2014

Accepted: December 29, 2014

\section{서 론}

혈청 creatinine은 근육 내에 존재하는 creatin의 탈수에 의해 생성되어 혈중에 출현하며 토리에서 여과된 후 재흡수 되지 않고 요 중으로 배설된다. 혈청 creatinine 수치만으로 단순히 콩팥의 기 능을 평가할 수는 없으나(Kissmeyer 등, 1999), 콩팥 질환에서 혈 청 creatinine의 상승은 진단 상 중요한 지표가 되며 임상적으로 중 요한 의의를 가진다. 또한 배설량은 주로 근육의 크레아틴 총량에 비례해서 성인에서는 체중 $\mathrm{kg}$ 당 거의 일정하고 식사 또는 요량 등 의 영향을 거의 받지 않으며, 요 중 creatinine은 생체 내 오염물질 의 농도 측정 시 사용하는 중요한 보정 물질로 사용되고 있다(Barr 등, 2005).

혈청 및 요의 creatinine 농도는 여러 방법에 의해 측정되는데 가 장 많이 사용되는 방법은 Jaffe 반응법이며, 이러한 creatinine 농
도를 이용하여 몇 가지 공식에 의해 계산된 creatinine clearance test 또한 토리여과율(glomerular filtration rate, GFR)과 밀접한 상관이 있어서 일반적으로 콩팥 기능의 지표로 널리 사용되고 있다 (Kang 등, 1998; Levey 등, 2000; Lin 등, 2003; Stevens 등, 2006).

현재 콩팥 관련 질환은 여러 만성 질환과 마찬가지로 조기발견 의 중요성이 강조되고 있는데(Striker, 1995; Hostetter, 2003), 각 종 질환의 선별검사에서 성인의 혈청 creatinine 정상치는 1 $\mathrm{mg} / \mathrm{dL}$ 내외이며 남녀 성별차이가 있음은 이미 알려져 있으나, 소 아 청소년에서 혈청 중의 creatinine농도는 성별 뿐 아니라 연령에 따라서 그 분포가 차이가 남에도 불구하고 그에 대한 자료는 부족 하다.

또한 요 중 creatinine 농도는 측정 시 수시요의 경우 요량 및 배 설량이 일정하지 않아 24 시간 요를 사용하는 것이 정확하여 이에 
대한 참고치만 알려져 있다. 그러나 24시간 요의 경우 검체 확보가 쉽지 않아 일반적인 선별 검사로는 수시요를 사용하게 되는데 이에 대한 자료는 거의 없는 실정이다.

이에 본 연구에서는 10 세 이상 20 세 미만 소아청소년의 연령과 성별에 따른 혈청과 요의 creatinine 농도를 살펴봄으로써 소아청 소년에 적합한 기초 자료를 제시하고자 하였다.

\section{재료 및 방법}

\section{1. 연구 대상}

제 5 기 국민건강영양조사(2011년 1월 12월)에서 검진을 시행 한 10 세 이상 20 세 미만 대상자 중 소변검사에서 이상 소견을 보인 대상자와 측정 결과가 누락된 결측치를 제외하고 건강한 소아청소 년 488명(남 278명, 여 210명)의 데이터를 대상으로 하였다. 본 연
구는 질병관리본부 연구윤리심의위원회의 승인을 받아 수행된 조 사 자료(승인번호: 2011-02CON-06-C)를 대상으로 분석을 시행 하였다.

\section{2. 연구 방법}

혈청 creatinine 검사를 위한 채혈은 8시간 이상 공복 상태에서 대상자들에게 시행하였으며, 요 creatinine 검사를 위한 채뇨는 각 대상자에게 조사 현장에서 중간 요 20 30 mL를 채취하여 냉장 보 관한 후 검사를 실시하였다. 혈청 및 요 creatinine은 CREA (Roche, USA) 시약을 사용하여 Jaffe 반응법으로 측정하였다. Jaffe 반응법은 알칼리에서 creatinine과 피크르산 이온이 반응하 여 creatinine-피크르산 복합체를 형성한 것으로 이를 파장 500 nm에서 Hitachi 7600 (Hitachi high-technologies Co., Tokyo, Japan) 자동화학 분석기를 이용하여 측정하였다.

Table 1. Mean serum creatinine levels, SD, Minimum and Maximum values according to age groups $(\mathrm{mg} / \mathrm{dL})$

\begin{tabular}{|c|c|c|c|c|c|c|c|c|c|}
\hline & \multirow{2}{*}{ Age (yr) } & \multirow{2}{*}{$\mathrm{N}$} & \multirow{2}{*}{ mean } & \multirow{2}{*}{$\mathrm{SD}$} & \multirow{2}{*}{ SE } & \multicolumn{2}{|c|}{$95 \%$ C.I. of mean } & \multirow{2}{*}{ Min } & \multirow{2}{*}{ Max } \\
\hline & & & & & & Lower & Upper & & \\
\hline \multirow[t]{11}{*}{ All } & 10 & 70 & 0.57 & 0.07 & 0.01 & 0.55 & 0.59 & 0.33 & 0.74 \\
\hline & 11 & 59 & 0.57 & 0.08 & 0.01 & 0.55 & 0.60 & 0.34 & 0.75 \\
\hline & 12 & 60 & 0.61 & 0.07 & 0.01 & 0.59 & 0.63 & 0.47 & 0.82 \\
\hline & 13 & 51 & 0.67 & 0.10 & 0.01 & 0.65 & 0.70 & 0.47 & 0.93 \\
\hline & 14 & 44 & 0.74 & 0.15 & 0.02 & 0.69 & 0.78 & 0.46 & 1.14 \\
\hline & 15 & 47 & 0.77 & 0.13 & 0.02 & 0.74 & 0.81 & 0.55 & 1.04 \\
\hline & 16 & 32 & 0.78 & 0.13 & 0.02 & 0.73 & 0.82 & 0.55 & 1.18 \\
\hline & 17 & 54 & 0.82 & 0.14 & 0.02 & 0.78 & 0.85 & 0.54 & 1.05 \\
\hline & 18 & 41 & 0.83 & 0.14 & 0.02 & 0.79 & 0.88 & 0.49 & 1.12 \\
\hline & 19 & 30 & 0.82 & 0.16 & 0.03 & 0.76 & 0.88 & 0.61 & 1.14 \\
\hline & total & 488 & 0.70 & 0.15 & 0.01 & 0.69 & 0.71 & 0.33 & 1.18 \\
\hline \multirow[t]{11}{*}{ Boys } & 10 & 37 & 0.58 & 0.08 & 0.01 & 0.55 & 0.60 & 0.33 & 0.74 \\
\hline & 11 & 31 & 0.59 & 0.08 & 0.01 & 0.56 & 0.62 & 0.44 & 0.75 \\
\hline & 12 & 40 & 0.62 & 0.07 & 0.01 & 0.59 & 0.64 & 0.50 & 0.78 \\
\hline & 13 & 33 & 0.69 & 0.11 & 0.02 & 0.65 & 0.72 & 0.49 & 0.93 \\
\hline & 14 & 25 & 0.81 & 0.14 & 0.03 & 0.75 & 0.86 & 0.57 & 1.14 \\
\hline & 15 & 28 & 0.83 & 0.13 & 0.02 & 0.78 & 0.88 & 0.55 & 1.04 \\
\hline & 16 & 14 & 0.87 & 0.13 & 0.04 & 0.80 & 0.95 & 0.72 & 1.18 \\
\hline & 17 & 28 & 0.92 & 0.09 & 0.02 & 0.88 & 0.96 & 0.73 & 1.05 \\
\hline & 18 & 28 & 0.89 & 0.12 & 0.02 & 0.84 & 0.94 & 0.63 & 1.12 \\
\hline & 19 & 14 & 0.97 & 0.09 & 0.02 & 0.92 & 1.02 & 0.81 & 1.14 \\
\hline & total & 278 & 0.74 & 0.17 & 0.01 & 0.72 & 0.77 & 0.33 & 1.18 \\
\hline \multirow[t]{11}{*}{ Girls } & 10 & 33 & 0.57 & 0.07 & 0.01 & 0.54 & 0.59 & 0.45 & 0.71 \\
\hline & 11 & 28 & 0.56 & 0.07 & 0.01 & 0.53 & 0.59 & 0.34 & 0.74 \\
\hline & 12 & 20 & 0.60 & 0.08 & 0.02 & 0.56 & 0.64 & 0.47 & 0.82 \\
\hline & 13 & 18 & 0.65 & 0.08 & 0.02 & 0.61 & 0.69 & 0.47 & 0.80 \\
\hline & 14 & 19 & 0.65 & 0.11 & 0.03 & 0.59 & 0.70 & 0.46 & 0.92 \\
\hline & 15 & 19 & 0.69 & 0.07 & 0.02 & 0.65 & 0.72 & 0.57 & 0.77 \\
\hline & 16 & 18 & 0.70 & 0.06 & 0.01 & 0.67 & 0.73 & 0.55 & 0.77 \\
\hline & 17 & 26 & 0.70 & 0.09 & 0.02 & 0.66 & 0.74 & 0.54 & 0.88 \\
\hline & 18 & 13 & 0.71 & 0.09 & 0.03 & 0.65 & 0.77 & 0.49 & 0.84 \\
\hline & 19 & 16 & 0.69 & 0.06 & 0.02 & 0.65 & 0.72 & 0.61 & 0.79 \\
\hline & total & 210 & 0.64 & 0.10 & 0.01 & 0.63 & 0.65 & 0.34 & 0.92 \\
\hline
\end{tabular}




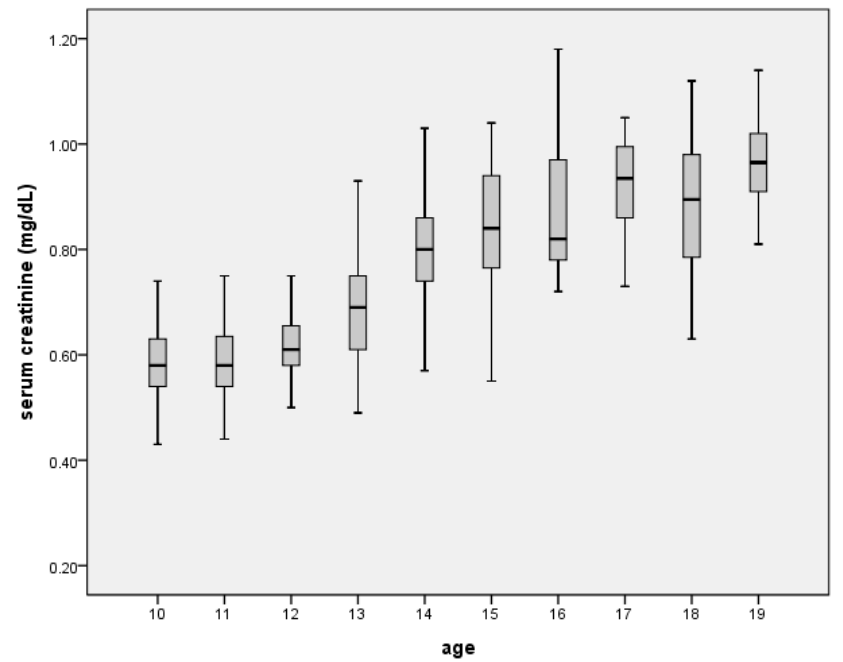

Fig. 1. Change of serum creatinine levels for the boys aged between 10 and 19 (Mean and 95\% Cl). The highest serum creatinine levels were found in boys aged 19 to 20 years, and the mean was $0.97 \mathrm{mg} / \mathrm{dL}$ ( $\min 0.81 \mathrm{mg} / \mathrm{dL}$, $\max 1.14 \mathrm{mg} / \mathrm{dL}$ ). The levels showed increase to those over 10 years old. C.I, confidence interval.

\section{3. 통계 분석}

연령과 성별에 따른 혈청 및 요의 creatinine 농도를 살펴보기 위 해 각 연령별 creatinine의 평균, 표준편차(SD), 평균에 대한 95\% 신뢰구간(lower limits, upper limits), 최소값과 최대값에 대한 기 술통계를 제시하였으며, 남녀 연령별 creatinine 농도의 분포에서 나타난 기술통계량들을 상자도표(box plot)로 제시하였다. 본 연 구에 포함된 대상자는 10 세 이상 20 세 미만 연령군으로서 연령의 구분은 만연령으로 하였으며, 10 세는 10 세 이상 11 세 미만을 나타 낸다. 혈청 및 요의 creatinine 평균 농도를 독립표본 $\mathrm{T}$-검정 (independent T-test)을 시행하여 연령 및 성별 평균의 차이를 검 증하였다. 각 성별 내 연령에 따른 creatinine 농도의 차이는 ANOVA (one-way)를 이용하여 분석한 후 Tukey HSD사후 검정 을 시행하였다. 자료 분석을 위한 통계프로그램은 SPSS 17.0 (SPSS, Inc., Chicago, IL, USA)을 사용하였으며, 결과 해석 시 $p<0.05$ 인 경우 유의한 것으로 판정하였다.

\section{결 과}

\section{1. 혈청 creatinine 농도}

전반적으로 혈청 creatinine의 평균 농도는 남녀 모두 연령이 증 가함에 따라 점차 증가하였다. 남자의 경우 혈청 creatinine의 평균 치는 $10 \sim 11$ 세에 $0.58 \mathrm{mg} / \mathrm{dL}(\min 0.33 \mathrm{mg} / \mathrm{dL}, \max 0.74$ $\mathrm{mg} / \mathrm{dL}$ )로 가장 낮고, 19 20세에서 $0.97 \mathrm{mg} / \mathrm{dL}$ ( $\min 0.81$ $\mathrm{mg} / \mathrm{dL}, \max 1.14 \mathrm{mg} / \mathrm{dL}$ )로 가장 높게 나타났다(Table 1, Fig. 1).

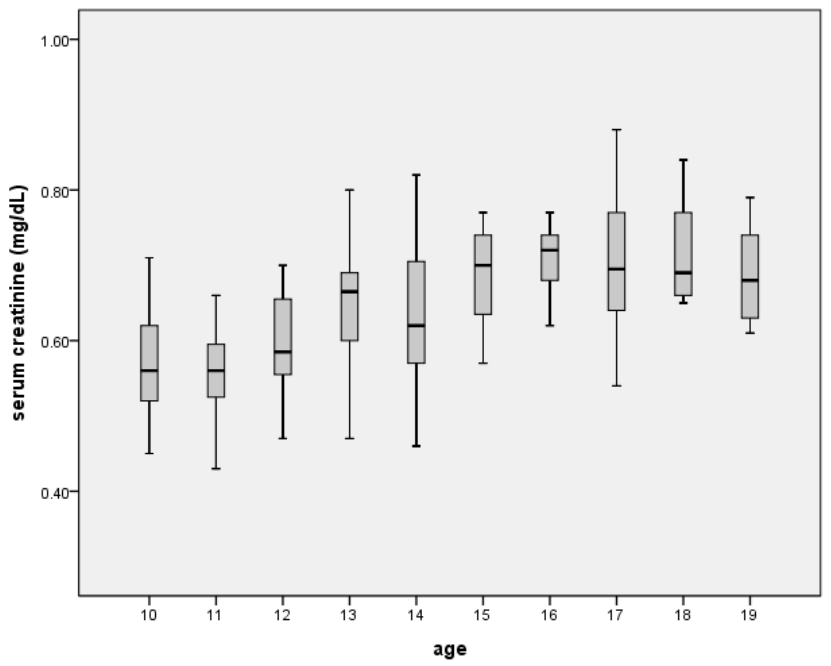

Fig. 2. Change of serum creatinine levels for the girls aged between 10 and 19 (Mean and 95\% Cl). The highest serum creatinine levels were found at those aged between 18 and 19 , and the mean was $0.71 \mathrm{mg} / \mathrm{dL}$ (min $0.49 \mathrm{mg} / \mathrm{dL}$, $\max 0.84 \mathrm{mg} / \mathrm{dL}$ ). The levels showed increase from 11 to 18 years old. C.I, confidence interval.

여자의 경우 혈청 creatinine의 평균치는 $10 \sim 11$ 세에 $0.57 \mathrm{mg} / \mathrm{dL}$ $(\min 0.45 \mathrm{mg} / \mathrm{dL}, \max 0.71 \mathrm{mg} / \mathrm{dL}$ )로 가장 낮고, 18 19세에서 $0.71 \mathrm{mg} / \mathrm{dL}$ ( $\min 0.49 \mathrm{mg} / \mathrm{dL}, \max 0.84 \mathrm{mg} / \mathrm{dL}$ )로 가장 높게 나 타났다(Table 1, Fig. 2).

성별에 따른 혈청 creatinine의 평균 농도는 전체 남자의 경우 $0.74 \mathrm{mg} / \mathrm{dL}$, 여자의 경우 $0.64 \mathrm{mg} / \mathrm{dL}$ 로 유의한 차이를 보였는데 $(p<0.05)$. 연령별로 나누어 살펴본 결과 $10 \sim 13$ 세 까지 성별에 따 른 평균차이는 보이지 않았다. 그러나 $14 \sim 15$ 세의 경우 남자 평균 $0.81 \mathrm{mg} / \mathrm{dL}(\min 0.57 \mathrm{mg} / \mathrm{dL}, \max 1.14 \mathrm{mg} / \mathrm{dL}$ ), 여자 평균 0.65 $\mathrm{mg} / \mathrm{dL}$ ( $\min 0.46 \mathrm{mg} / \mathrm{dL}, \max 0.92 \mathrm{mg} / \mathrm{dL}$ )로 나타나 14 세 이후 부터는 유의한 차이를 보였다 $(p<0.05)$. 남녀 각각의 성별군 내에 서 평균의 차이를 Tukey HSD에 의한 다중비교를 통해 사후 분석한 결과 평균의 차이를 보이지 않아 동일 집단으로 간주할 수 있는 연 령군은 남자의 경우 $10 \sim 13$ 세, 14 16세, 17 19세, 여자의 경우 10 12세, 13세 19세로 나타났다(Table 2).

\section{2. 요 creatinine 농도}

연령에 따른 요 creatinine의 평균 농도는 남자의 경우 $11 \sim 12$ 세에 $117.51 \mathrm{mg} / \mathrm{dL}$ ( $\min 41 \mathrm{mg} / \mathrm{dL}, \max 248 \mathrm{mg} / \mathrm{dL}$ )로 가장 낮 고, 19 20세에서 $222.68 \mathrm{mg} / \mathrm{dL}(\min 133 \mathrm{mg} / \mathrm{dL}$, $\max 324$ $\mathrm{mg} / \mathrm{dL}$ )로 가장 높게 나타났다(Table 3, Fig. 3). 여자의 경우 11 12세에 $100.00 \mathrm{mg} / \mathrm{dL}(\min 34 \mathrm{mg} / \mathrm{dL}, \max 201 \mathrm{mg} / \mathrm{dL}$ )로 가장 낮고, 14 15세에 $218.44 \mathrm{mg} / \mathrm{dL}$ (min $131 \mathrm{mg} / \mathrm{dL}$, $\max 321$ $\mathrm{mg} / \mathrm{dL}$ )로 가장 높고, 그 다음으로 19 20세에 $203.89 \mathrm{mg} / \mathrm{dL}$ (min $59 \mathrm{mg} / \mathrm{dL}, \max 398 \mathrm{mg} / \mathrm{dL}$ ) 높게 나타났다(Table 3, Fig. 4). 
120 Se-Young Kwon and Young-Ak Na. Concentration of Creatinine in Pediatrics

Table 2. Comparison of mean serum creatinine levels based on age groups $(\mathrm{mg} / \mathrm{dL})$

\begin{tabular}{|c|c|c|c|c|c|}
\hline Age (yr) & Boys & Girls & $p$ value ${ }^{\star}$ & $\mathrm{T}^{+}$ & $T^{\dagger}$ \\
\hline 10 & 0.58 & 0.57 & 0.593 & a & $a, b$ \\
\hline 11 & 0.59 & 0.56 & 0.117 & $a$ & a \\
\hline 12 & 0.62 & 0.60 & 0.498 & $a, b$ & $a, b, c$ \\
\hline 13 & 0.69 & 0.65 & 0.254 & b & $c, d$ \\
\hline 14 & 0.81 & 0.65 & $<0.001$ & C & $b, c, d$ \\
\hline 15 & 0.83 & 0.69 & $<0.001$ & $c, d$ & d \\
\hline 16 & 0.87 & 0.70 & $<0.001$ & $c, d$ & $d$ \\
\hline 17 & 0.92 & 0.70 & $<0.001$ & $\mathrm{~d}, \mathrm{e}$ & $d$ \\
\hline 18 & 0.89 & 0.71 & $<0.001$ & $c, d, e$ & d \\
\hline 19 & 0.97 & 0.69 & $<0.001$ & e & $d$ \\
\hline total & 0.74 & 0.64 & $<0.001$ & & \\
\hline
\end{tabular}

* Statistical significance was tested by t-test.

†The same letters indicate non-significant difference between age groups based on Tukey's HSD multiple comparison test in boys.

${ }^{\ddagger}$ The same letters indicate non-significant difference between age groups based on Tukey's HSD multiple comparison test in girls.

Table 3. Mean urine creatinine levels, SD, Minimum and Maximum values according to age groups (mg/dL)

\begin{tabular}{|c|c|c|c|c|c|c|c|c|c|}
\hline & \multirow{2}{*}{ Age (yr) } & \multirow{2}{*}{ N } & \multirow{2}{*}{ mean } & \multirow{2}{*}{ SD } & \multirow{2}{*}{ SE } & \multicolumn{2}{|c|}{$95 \%$ C.I. of mean } & \multirow{2}{*}{ Min } & \multirow{2}{*}{ Max } \\
\hline & & & & & & Lower & Upper & & \\
\hline \multirow[t]{11}{*}{ All } & 10 & 70 & 131.47 & 52.70 & 6.30 & 118.91 & 144.04 & 41 & 285 \\
\hline & 11 & 59 & 109.20 & 49.30 & 6.42 & 96.35 & 122.05 & 34 & 248 \\
\hline & 12 & 60 & 134.62 & 53.35 & 6.89 & 120.84 & 148.40 & 25 & 277 \\
\hline & 13 & 51 & 162.38 & 67.03 & 9.39 & 143.53 & 181.24 & 53 & 344 \\
\hline & 14 & 44 & 195.81 & 75.18 & 11.34 & 172.95 & 218.67 & 39 & 362 \\
\hline & 15 & 47 & 196.76 & 79.47 & 11.59 & 173.43 & 220.09 & 45 & 392 \\
\hline & 16 & 32 & 197.79 & 84.81 & 14.99 & 167.22 & 228.37 & 39 & 411 \\
\hline & 17 & 54 & 181.71 & 71.48 & 9.73 & 162.20 & 201.22 & 69 & 362 \\
\hline & 18 & 41 & 187.79 & 67.50 & 10.54 & 166.48 & 209.09 & 57 & 313 \\
\hline & 19 & 30 & 212.66 & 78.08 & 14.26 & 183.50 & 241.81 & 59 & 398 \\
\hline & total & 488 & 164.12 & 73.87 & 3.34 & 157.55 & 170.69 & 25 & 411 \\
\hline \multirow[t]{11}{*}{ Boys } & 10 & 37 & 131.72 & 52.50 & 8.63 & 114.21 & 149.22 & 41 & 285 \\
\hline & 11 & 31 & 117.51 & 51.58 & 9.26 & 98.59 & 136.43 & 41 & 248 \\
\hline & 12 & 40 & 147.75 & 54.52 & 8.62 & 130.31 & 165.18 & 25 & 277 \\
\hline & 13 & 33 & 164.58 & 56.76 & 9.88 & 144.45 & 184.70 & 81 & 277 \\
\hline & 14 & 25 & 178.62 & 82.79 & 16.56 & 144.44 & 212.79 & 39 & 362 \\
\hline & 15 & 28 & 200.69 & 86.61 & 16.37 & 167.10 & 234.27 & 74 & 392 \\
\hline & 16 & 14 & 222.09 & 90.12 & 24.09 & 170.06 & 274.13 & 72 & 411 \\
\hline & 17 & 28 & 201.63 & 69.49 & 13.13 & 174.68 & 228.57 & 80 & 362 \\
\hline & 18 & 28 & 201.74 & 68.31 & 12.91 & 175.25 & 228.22 & 78 & 313 \\
\hline & 19 & 14 & 222.68 & 69.79 & 18.65 & 182.38 & 262.98 & 133 & 324 \\
\hline & total & 278 & 170.73 & 73.88 & 4.43 & 162.01 & 179.45 & 25 & 411 \\
\hline \multirow[t]{11}{*}{ Girls } & 10 & 33 & 131.20 & 53.75 & 9.36 & 112.14 & 150.26 & 43 & 251 \\
\hline & 11 & 28 & 100.00 & 45.80 & 8.66 & 82.24 & 117.76 & 34 & 201 \\
\hline & 12 & 20 & 108.38 & 40.59 & 9.08 & 89.38 & 127.38 & 51 & 211 \\
\hline & 13 & 18 & 158.36 & 84.42 & 19.90 & 116.38 & 200.34 & 53 & 344 \\
\hline & 14 & 19 & 218.44 & 58.43 & 13.41 & 190.27 & 246.60 & 131 & 321 \\
\hline & 15 & 19 & 190.98 & 69.49 & 15.94 & 157.48 & 224.47 & 45 & 286 \\
\hline & 16 & 18 & 178.89 & 77.72 & 18.32 & 140.24 & 217.54 & 39 & 315 \\
\hline & 17 & 26 & 160.26 & 68.52 & 13.44 & 132.58 & 187.94 & 69 & 290 \\
\hline & 18 & 13 & 157.74 & 57.06 & 15.83 & 123.26 & 192.22 & 57 & 259 \\
\hline & 19 & 16 & 203.89 & 85.97 & 21.49 & 158.08 & 249.70 & 59 & 398 \\
\hline & total & 210 & 155.36 & 73.12 & 5.05 & 145.42 & 165.31 & 34 & 398 \\
\hline
\end{tabular}




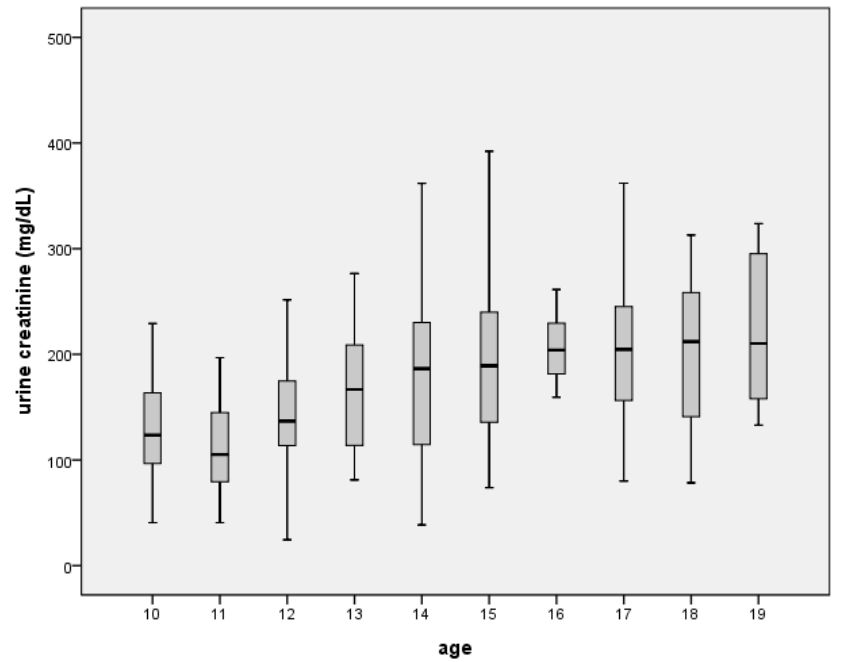

Fig. 3. Change of urine creatinine levels for the boys aged between 10 and 19 (Mean and $95 \% \mathrm{Cl}$ ). The highest urine creatinine levels were found in boys aged 19 to 20 years, and the mean was 222.68 $\mathrm{mg} / \mathrm{dL}$ ( $\min 133 \mathrm{mg} / \mathrm{dL}$, max $324 \mathrm{mg} / \mathrm{dL}$ ). The levels showed increase to those over 11 years old. C.I, confidence interval.

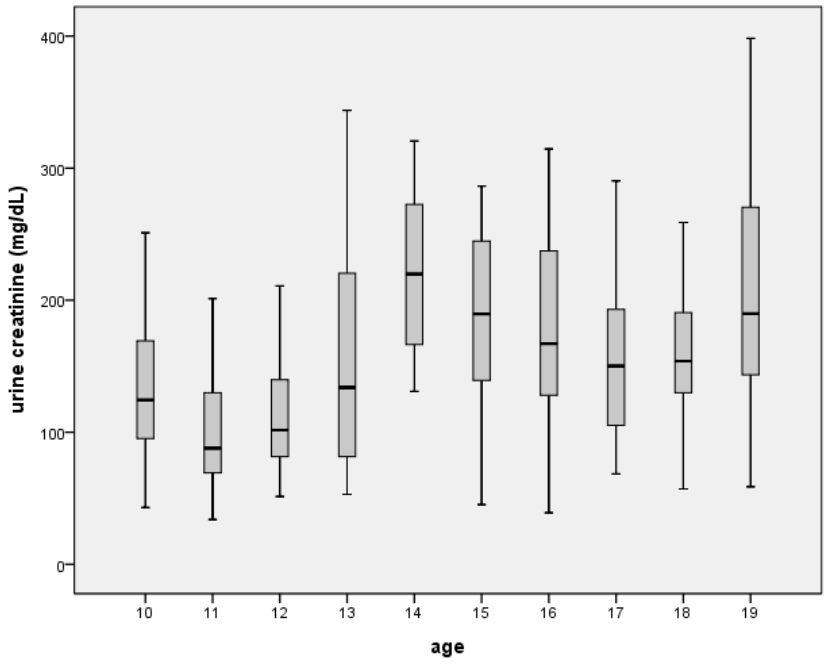

Fig. 4. Change of urine creatinine levels for the girls aged between 10 and 19 (Mean and 95\% Cl). The highest urine creatinine levels were found in girls aged 14 to 15 years, and the mean was 218.44 $\mathrm{mg} / \mathrm{dL}(\min 131 \mathrm{mg} / \mathrm{dL}$, $\max 321 \mathrm{mg} / \mathrm{dL}$ ). The levels showed increase from 11 to 14 years old. C.I, confidence interval.

Table 4. Comparison of mean urine creatinine levels based on age groups (mg/dL)

\begin{tabular}{cccccc}
\hline Age $(\mathrm{yr})$ & Boys & Girls & $p$ value & $\mathrm{T}^{\dagger}$ & $\mathrm{T}^{\ddagger}$ \\
\hline 10 & 131.72 & 131.20 & 0.968 & $\mathrm{a}, \mathrm{b}$ & $\mathrm{a}, \mathrm{b}$ \\
11 & 117.51 & 100.00 & 0.175 & $\mathrm{a}$ & $\mathrm{a}$ \\
12 & 147.75 & 108.38 & 0.006 & $\mathrm{a}, \mathrm{b}, \mathrm{c}$ & $\mathrm{a}$ \\
13 & 164.58 & 158.36 & 0.755 & $\mathrm{a}, \mathrm{b}, \mathrm{c}, \mathrm{d}, \mathrm{c}$ & $\mathrm{c}$ \\
14 & 178.62 & 218.44 & 0.082 & $\mathrm{~b}, \mathrm{c}, \mathrm{d}, \mathrm{c}$ & $\mathrm{b}, \mathrm{c}$ \\
15 & 200.69 & 190.98 & 0.686 & $\mathrm{~d}, \mathrm{~d}$ & $\mathrm{a}, \mathrm{b}, \mathrm{c}$ \\
16 & 222.09 & 178.89 & 0.156 & $\mathrm{c}, \mathrm{d}$ & $\mathrm{a}, \mathrm{b}, \mathrm{c}$ \\
17 & 201.63 & 160.26 & 0.032 & $\mathrm{~d}$ & $\mathrm{c}$ \\
18 & 201.74 & 157.74 & 0.051 & 0.520 & \\
\hline
\end{tabular}

* Statistical significance was tested by t-test.

${ }^{\dagger}$ The same letters indicate non-significant difference between age groups based on Tukey's HSD multiple comparison test in boys.

${ }^{\ddagger}$ The same letters indicate non-significant difference between age groups based on Tukey's HSD multiple comparison test in girls.

성별에 따른 요 creatinine의 평균 농도는 전체 남자의 경우 $170.73 \mathrm{mg} / \mathrm{dL}$, 여자의 경우 $155.36 \mathrm{mg} / \mathrm{dL}$ 로 유의한 차이를 보였 는데 $(p<0.05), 12 \sim 13$ 세 연령군(남자 $147.75 \mathrm{mg} / \mathrm{dL}$, 여자의 경 우 $108.38 \mathrm{mg} / \mathrm{dL}$ )과 $17 \sim 18$ 세 연령군(남자 $201.63 \mathrm{mg} / \mathrm{dL}$, 여자 의 경우 $160.26 \mathrm{mg} / \mathrm{dL})$ 에서는 유의한 차이를 보였으나 $(p<0.05)$, 이를 제외한 나머지 연령군에서는 성별에 따른 유의한 차이는 나타 나지 않았다. 남녀 각각의 성별군 내에서 평균의 차이를 Tukey $\mathrm{HSD}$ 에 의한 다중비교를 통해 사후 분석한 결과 평균의 차이를 보 이지 않아 동일 집단으로 간주할 수 있는 연령군은 남자와 여자 모 두에서 10 12세, 13 19세로 나타났다(Table 4).

\section{고 찰}

creatinine은 연령과 성별에 따라 차이가 있다고 알려져 있는데, 체내에서 매일 creatin이 creatinine으로 일부 전환되는 양의 감소 및 근육과 토리 여과율의 감소로 연령이 증가함에 따라 감소하며, 남성이 여성보다 수치가 높다고 하였다(Bjornsson, 1979; O'Rourke 등, 2000; Mage 등, 2004; Barr 등, 2005; NIER, 2008; Lee와 Ahn, 2010). 본 연구에서는 10세 이상 20세 미만 소아청소 년의 혈청과 요 중 creatinine 농도를 성별과 연령에 따라 나누어 살 펴보았는데, 전반적으로 혈청 creatinine의 평균 농도는 성인과 달 리 남녀 모두 연령이 증가함에 따라 점차 증가하였다. 우리나라 성 인의 혈청 creatinine의 평균치는 남자의 경우 1.05-1.08 \pm 0.1 
$\mathrm{mg} / \mathrm{dL}$, 여자의 경우 0.81-0.82 $\pm 0.1 \mathrm{mg} / \mathrm{dL}$ 인데(Jin 등, 1996; Lee 등, 2004; Chin 등, 2007), 본 연구 대상자인 소아청소년의 경 우 혈청 creatinine의 평균 농도는 남자의 경우 $0.74 \mathrm{mg} / \mathrm{dL}$, 여자 의 경우 $0.64 \mathrm{mg} / \mathrm{dL}$ 로 성인의 평균치 보다 낮게 나타나 연령 증가 에 따른 감소는 성인 이후에 적용됨을 알 수 있었다. 혈청 뿐 아니라 요 creatinine의 평균 농도도 전체 남자의 경우 $170.73 \mathrm{mg} / \mathrm{dL}$, 여 자의 경우 $155.36 \mathrm{mg} / \mathrm{dL}$ 로 나타나 성별에 따른 농도는 소아 청소 년의 경우에도 남성이 여성보다 높게 나타났으며 이는 성인 대상의 선행 결과와 유사하였다.

연령에 따른 변화는 혈청 creatinine의 경우 분명한 증가 경향을 보였으나, 요 creatinine의 경우 남자에서는 증가 경향을 보였으나 여자에서는 그 경향이 뚜렷하지는 않았다. 이는 요 중 creatinine 농도 측정 시 수시요의 경우 요량 및 배설량이 일정하지 않아 24시 간 요를 사용하는 것이 정확하여 일반적으로 24시간 요 검체로 분 석하는 것이 원칙인데 본 연구는 수시요를 분석한 자료이므로 그 한계가 있을 수 있다. 그러나 24시간 요의 경우 검체 확보가 쉽지 않 아 일반적인 선별 검사로는 수시요를 사용하게 되는데(Spierto 등, 1997; Carrieri 등, 2001) 수시요에 대한 자료는 거의 없는 실정이 므로 연령 및 성별에 따른 분포를 파악하는 기초 자료로 활용 하는 데는 무리가 없을 것이다.

또한 본 연구에서 혈청 및 요 creatinine은 Jaffe 반응법으로 측 정한 분석 자료인데 현재 우리나라의 경우 임상정도관리검사에 제 시하는 creatinine 검사코드 총 10 개 중에서 검사 코드 4 (kinetic alkaline picrate)를 사용하는 기관이 전체의 $70 \%$ 로 가장 사용 비 율이 높고, 검사 코드 8 (Rate-blanked and compensated kinetic alkaline picrate)을 사용하는 기관이 14\%, 검사 코드 3 (Alkaline picrate without Lloyd's reagent)을 사용하는 기관이 8\%, 검사 코 드 9 (Compensated kinetic alkaline picrate)를 사용하는 기관이 $2 \%$ 로 전체 기관의 약 $94 \%$ 에 해당하는 기관이 Jaffe 반응을 응용한 방법을 사용하고 있고, 그 외 효소법을 사용하는 기관이 전체의 $4 \%$, 기타 검사법이 $2 \%$ 를 차지하고 있다(KAQA, 2014). 따라서 본 연구 에서 제시한 결과는 Jaffe 반응법을 사용하는 대부분의 검사실에서 참고 자료로 이용할 수 있을 것이다.

소아청소년의 혈청과 요 중 creatinine 농도에 적합한 기초 자료 를 제시하기 위해 최종적으로는 참고치를 설정하는 것이 필요한데, 참고범위는 각 검사기관에서 그 대상 집단에 맞춰 자체적으로 설정 해야 한다(Fischbach와 Zawta 1992). David 등(2012)은 캐나다 의 18세 이하 소아청소년 2188명을 대상으로 한 대규모 연구 (Canadian Laboratory Initiative in Pediatric Reference Intervals, CALIPER)에서 혈중 지표들의 연령 - 성별에 따른 참고 범위를 제시하였는데, 혈청 creatinine 농도의 경우 효소법은 5
12세, 12 15세, 15 19세로 연령을 세분화하였고, 15세 미만까 지는 남녀 모두 동일하나, 15 19세의 경우 남자 0.62-1.08 $\mathrm{mg} / \mathrm{dL}$, 여자 0.49-0.84 mg/dL로 성별에 따라각각 다르게 명시하 였다. Jaffe 반응법은 7 12세, 12 15세, 15 17세, 17 19세로 연령을 더 세분화하였고, 15세 미만까지는 남녀 모두 동일하나, 15 17세의 경우 남자 0.65-1.04 mg/dL, 여자 0.59-0.86 mg/dL, $17 \sim 19$ 세의 경우 남자 $0.69-1.10 \mathrm{mg} / \mathrm{dL}$, 여자 $0.60-0.88 \mathrm{mg} / \mathrm{dL}$ 로 성별에 따라 각각 다르게 명시하였다. 본 연구에서 연령별로 나 누어 참고치를 제시하기에는 본 연구 대상자의 수가 적어 한계가 있었으나, 남녀 각각의 성별군 내에서 평균의 차이를 다중비교를 통해 사후 분석한 결과 동일 집단으로 간주할 수 있는 연령군은 혈 청 creatinine 농도의 경우 남자 10 13세, 14 16세, 17 19세, 여자 10 12세, 13세 19세로 나타났으며, 요 creatinine 농도의 경우 남자와 여자 모두에서 10 12세, 13 19세로 나타났으므로, 추후 대상자를 더 확보하여 참고치 설정 시 성별에 따라 각각 해당 그룹으로 나누고 참고 범위를 따로 제시하는 것이 타당할 것으로 보인다. 또한 세분화할 연령군이 외국의 경우와 다를 수 있으므로 우리나라 대상자에 적합한 연령군 설정이 필요할 것이다.

본 연구에서 10세 이상 20세 미만 소아청소년의 혈청과 요 중 creatinine 농도에 대한 기초 자료를 제시하고자 연령과 성별에 따 른 농도의 분포를 살펴보았다. 혈청과 요 creatinine 농도는 성별. 연령별 변화 양상이 성인과 다르며 추후 참고치 설정 시 연령군별 로 따로 설정되어야함을 알 수 있었으며 추후 임상에서 유용하게 활용될 수 있도록 우리나라 실정에 맞는 자료의 보완이 필요하다.

\section{Acknowledgements: None}

Funding: None

Conflict of interest: None

\section{References}

1. Barr DB, Wilder LC, Caudill SP, Gonzalez AJ, Needham LL. Pirkle J. Urinary creatinine concentrations in the U.S. population: implications for urinary biologic monitoring measurements. Environmental Health Perspectives. 2005, 113(2):192-200.

2. Bjornsson TD. Use of serum creatinine concentrations to determine renal function. Clin Pharmacokinet. 1979, 4:200-222.

3. Carrieri M, Trevisan A, Bartolucci GB. Adjustment to concentration - dilution of spot urine sample: correlation between specific gravity and creatinine. Int Arch Occup Environ Health. 2001, 74:63-67.

4. Chin HJ, Oh KH, Oh YK, Na KY, Joo KW, Lim CS, Kim YS, Chae DW, Ahn C, Han JS, Lee JS, Kim S. The prevalence and the associated disorders of chronic kidney disease in subjects with health check-up. Korean J Nephrol. 2007, 26:195-203. 
5. David AC, Lianna K, Man KC, Caitlin HD, Davor B, Allison AV, et al. Closing the Gaps in Pediatric Laboratory Reference Intervals: A CALIPER Database of 40 Biochemical Markers in a Healthy and Multiethnic Population of Children. Clin Chem. 2012, 58(5):854-868.

6. Fischbach F, Zawta B. Age-dependent Reference Limits of Several Enzymes in Plasma at Different Measuring Temperatures. Klin Lab. 1992, 38:556-561.

7. Hostetter TH: Prevention of the development nd progression of renal disease. J Am Soc Nephrol. 2003, 14 (Suppl 2):S144-147.

8. Jin DC, Yoon YS, Shin YS, Song HC, Park CW, Ahn SJ, Kim SY, Choi EJ, Chang YS, Bang BK: Renal function and prevalence of adult diseases in asymptomatic Korean. Korean J Med. 1996, 51:614-621.

9. Kang WH, Seo GH, Lee BH, Kim B, Lee SK, Oh JD, et al. Estimation of creatinine clearance with serum creatinine Korean patients. The Korean Journal of Nephrology. 1998, 17(6):866-871.

10. KAQA (Korean Association of Quality Assurance). http://www.lab-qa.org/, last visited on 24 October 2014.

11. Kissmeyer L, Kong C, Cohen J, Unwin RJ, Woolfson RG, Neild GH: Community nephrology: Audit of screening for renal insufficiency in a high risk population. Nephrol Dial Transplant. 1999, 14:2150-2155.

12. Lee J, Kim J, Park I, Lim S, Song K, Cho H, Shin G, Kim H, Kim K: A study on the appropriate normal range of serum creatinine level for Koreans. Korean J Nephrol. 2004, 23:721-728.

13. Lee JH, Ahn RM. Relevance ofgender,age and the body mass in- dex to changes in urinary creatinine concentration in Korean adults. J Env HIth Sci. 2010, 36(3):215-221.

14. Levey AS, Greene T, Kusek J, Beck GJ, Group MS. A simplified equation to predict glomerular filtration rate from serum creatinine. J Am Soc Nephrol. 2000, 11:A0828.

15. Lin J, Knight EL, Hogan ML, Singh AK: A comparison of prediction equations for estimating glomerular filtration rate in adults without kidney disease. J Am Soc Nephrol. 2003, 14:2573-2580.

16. Mage DT, Allen RH, Gondy G, Smith W, Barr DB, Needham LL. Estimating pesticide dose from urinary pesticide concentration data by creatinine correction in the Third National Health and Nutrition Examination Survey(NHANES-III). Journal of Exposure Analysis and Environmental Epidemiology. 2004, 14:457-465.

17. NIER (National Institute of Environmental Research). Research of toxic substance in biomarkers of residents in Korea. Seoul: Ministry of Environmental. 2008.

18. O'Rourke MK, Lizardi PS, Rogan SP, Freeman NC, Aguirre A, Saint CG. Pesticide exposure and creatinine variation among young children. J Expo Anal Environ Epidemiol. 2000, 10:672-681.

19. Spierto FW, Hannon WH, Gunter EW, Smith SJ. Stability of urine creatinine. Clinica Chimica Acta. 1997, 264:227-232.

20. Stevens LA, Coresh J, Greene T, Levey AS: Assessing Kidney Function Measured and estimated glomerular filtration rate. $N$ Engl J Med. 2006, 354:2473-2483.

21. Striker GE: Report on a workshop to develop management recommendations for the prevention of progression in chronic renal disease, Bethesda(MA) April 1994. Nephrol Dial Transplant. 1995, 10: 290-292. 